Vapor Space Characterization of Waste Tank 241-BY-103 (In Situ): Results from Samples Collected on 5/5/94
M. W. Ligotke
K. H. Pool
A. K. Sharma
R. B. Lucke
B. D. McVeety
M. McCulloch
J. S. Fruchter
S. C. Goheen

June 1995

Prepared for Westinghouse Hanford Company under a Related Services Agreement with the U.S. Department of Energy Contract DE-AC06-76RLO 1830

Pacific Northwest Laboratory Operated for the U.S. Department of Energy by Battelle Memorial Institute 


\section{DISCLAIMER}

This report was prepared as an account of work sponsored by an agency of the United States Government. Neither the United States Government nor any agency thereof, nor Battelle Memorial Institute, nor any of their employees, makes any warranty, expressed or implied, or assumes any legal liability or responsibility for the accuracy, completeness, or usefulness of any information, apparatus, product; or process disclosed, or represents that its use would not infringe privately owned rights. Reference herein to any specific commercial product, process, or service by trade name, trademark, manufacturer, or otherwise does not necessarily constitute or imply its endorsement, recommendation, or favoring by the United States Government or any agency thereof, or Battelle Memorial Instifute. The views and opinions of authors expressed herein do not neces sarily state or reflect those of the United States Government or any agency thereof.

\section{PACIFIC NORTHWEST LABORATORY operated by \\ BATTELLE MEMORIALINSTITUTE for the \\ UNITED STATES DEPARTMENT OF ENERGY under Contract DE-ACO6-76RLO 1830}

Printed in the United States of America

Available to DOE and DOE contractors from the

Office of Scientific and Technical Information, P,O.Box 62, Oak Ridge, TN 37831; prices available from (615) 576-8401. FTS 626-8401.

Available to the public from the National Technical Information Service, U.S. Department of Commerce, 5285 Port Royal Rd., Springfield, VA 22161. 


\section{DISCLAIMER}

Portions of this document may be illegible in electronic image products. Images are produced from the best available original document. 
This report was prepared as an account of work sponsored by an agency of the United States Government. Neither the United States Government nor any agency thereof, nor any of their employees, makes any warranty, express or implied, or assumes any legal liability or responsibility for the accuracy, completeness, or usefulness of any information, apparatus, product, or process disclosed, or represents that its use would not infringe privately owned rights. Reference herein to any specific commercial product, process, or service by trade name, trademark, manufacturer, or otherwise does not necessarily constitute or imply its endorsement, recommendation, or favoring by the United States Government or any agency thereof. The views and opinions of authors expressed herein do not necessarily state or reflect those of the United States Government or any agency thereof.

\title{
Vapor Space Characterization of Waste \\ Tank 241-BY-103 (In Situ): Results from Samples Collected on 5/5/94
}

\author{
M. W. Ligotke \\ K. H. Pool \\ A. K. Sharma \\ R. B. Lucke \\ B. D. McVeety \\ M. McCulloch \\ J. S. Fruchter \\ S. C. Goheen
}

June 1995

Prepared for Westinghouse Hanford Company

under a Related Services Agreement

with the U.S. Department of Energy

Contract DE-AC06-76RLO 1830

Pacific Northwest Laboratory

Richland, Washington 99352 


\section{Summary}

This report describes inorganic and organic analyses results from in situ samples obtained from the tank headspace of the Hanford waste storage Tank 241-BY-103 (referred to as Tank BY-103). The results described here were obtained to support safety and toxicological evaluations. A summary of the results for inorganic and organic analytes is listed in Table 1. Detailed descriptions of the results appear in the text.

Quantitative results were obtained for the inorganic compounds $\mathrm{NH}_{3}, \mathrm{NO}_{2}, \mathrm{NO}, \mathrm{HCN}$, and $\mathrm{H}_{2} \mathrm{O}$. Sampling for sulfur oxides was not requested. Organic compounds were also quantitatively determined. Twenty-three tentatively identified organic analytes were observed above the detection limit of (ca.) 10 ppbv, but standards for most of these were not available at the time of analysis, and their quantitation is beyond the scope of this study. In addition, we looked for the 41 standard TO-14 analytes. Of these, only a few were observed above the 2-ppbv detection limit. The 11 organic analytes with the highest estimated concentrations are listed in Table 1 . The 11 analytes account for approximately $76 \%$ of the total organic components in Tank BY-103. The remaining $24 \%$ is made up of the other tentatively identified compounds listed in Table 3.2.

Table 1. Summary Results of Inorganic and Organic Samples Collected from the Tank Headspace of Tank BY-103 on 5/5/94

\begin{tabular}{|c|c|c|c|}
\hline Category & Analyte & $\begin{array}{l}\text { Vapor }^{(a)} \\
\text { Concentration }\end{array}$ & Units \\
\hline Inorganic & $\begin{array}{l}\mathrm{NH}_{3} \\
\mathrm{NO}_{2} \\
\mathrm{NO} \\
\mathrm{HCN} \\
\mathrm{H}_{2} \mathrm{O}\end{array}$ & $\begin{aligned} 30.7 & \pm 0.4 \\
& \leq 0.1 \\
& \leq 0.2 \\
& \leq 0.005 \\
8.9 & \pm 1.0\end{aligned}$ & $\begin{array}{l}\text { ppmv } \\
\text { ppmv } \\
\text { ppmv } \\
\text { ppmv } \\
\mathrm{mg} / \mathrm{L}\end{array}$ \\
\hline Organic & $\begin{array}{l}\text { Acetone } \\
\text { 2-Butanone } \\
\text { n-Butanol } \\
\text { C7 alkanes } \\
\text { 3-Methylhexane } \\
\text { n-Heptane } \\
\text { Methylcyclohexane } \\
\text { 2-Butoxyethanol } \\
\text { n-Decane } \\
\text { n-Tridecane } \\
\text { n-Tetradecane }\end{array}$ & $\begin{array}{l}0.59 \\
0.10 \\
0.13 \\
0.17 \\
0.24 \\
0.14 \\
0.31 \\
0.14 \\
0.23 \\
0.45 \\
0.10\end{array}$ & $\begin{array}{l}\mathrm{mg} / \mathrm{m}^{3} \\
\mathrm{mg} / \mathrm{m}^{3} \\
\mathrm{mg} / \mathrm{m}^{3} \\
\mathrm{mg} / \mathrm{m}^{3} \\
\mathrm{mg} / \mathrm{m}^{3} \\
\mathrm{mg} / \mathrm{m}^{3} \\
\mathrm{mg} / \mathrm{m}^{3} \\
\mathrm{mg} / \mathrm{m}^{3} \\
\mathrm{mg} / \mathrm{m}^{3} \\
\mathrm{mg} / \mathrm{m}^{3} \\
\mathrm{mg} / \mathrm{m}^{3}\end{array}$ \\
\hline
\end{tabular}

(a) Vapor concentrations were determined using sample-volume data provided by Westinghouse Hanford Company and are based on averaged data. 


\section{Acknowledgments}

The authors gratefully acknowledge the support of other project staff at Pacific Northwest Laboratory who contributed to the successful completion of this sampling and analysis activity. Jeff Edwards served as the PNL single-point-of-contact and coordinated sample handling and communications with Westinghouse Hanford Company. Bruce Lerner performed method development and validation work that supported the inorganic vapor sampling. Sally Slate and May-Lin Thomas analyzed inorganic samples, and Annalisa Krupsha and Gary Dennis prepared the solid-sorbent sample trains. Therese Clauss assisted in preparing this report. Georgia Ruebsamen provided word processing support. 



\section{Abbreviations}

$\begin{array}{ll}\text { CAS } & \text { Chemical Abstracts Service } \\ \text { COC } & \text { chain of custody } \\ \text { DIW } & \text { deionized water } \\ \text { emf } & \text { electromotive force } \\ \text { EPA } & \text { U.S. Environmental Protection Agency } \\ \text { GC/MS } & \text { gas chromatography/mass spectrometry } \\ \text { HP } & \text { Hewlett Packard } \\ \text { IC } & \text { ion chromatography } \\ \text { IL } & \text { impact level } \\ \text { IS } & \text { internal standard } \\ \text { ISS } & \text { in situ sampling } \\ \text { MDL } & \text { minimum detection limit } \\ \text { NIST } & \text { National Institute for Standards and Technology } \\ \text { NPH } & \text { normal paraffin hydrocarbon } \\ \text { OSHA } & \text { Occupational Safety and Health Administration } \\ \text { PFA } & \text { perflouroalkoxy } \\ \text { PNL } & \text { Pacific Northwest Laboratory } \\ \text { ppbv } & \text { part-per-billion by volume } \\ \text { ppmv } & \text { part-per-million by volume } \\ \text { QA } & \text { quality assurance } \\ \text { REL } & \text { recommended exposure limit } \\ \text { SCIC } & \text { suppressed-conductivity ion chromatography } \\ \text { SIE } & \text { selective ion electrode } \\ \text { SRM } & \text { standard reference material } \\ \text { STP } & \text { standard temperature and pressure } \\ \text { TEA } & \text { triethanolamine } \\ \text { TIC } & \text { tentatively identified compound } \\ \text { VSS } & \text { vapor sampling system } \\ \text { WHC } & \text { Westinghouse Hanford Company }\end{array}$





\section{Contents}

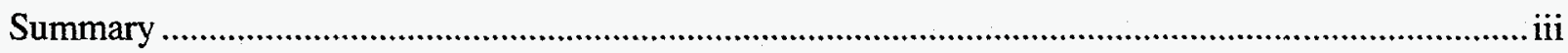

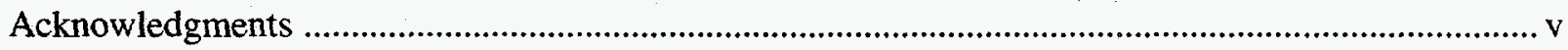

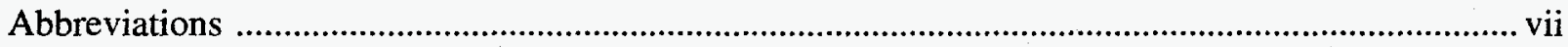

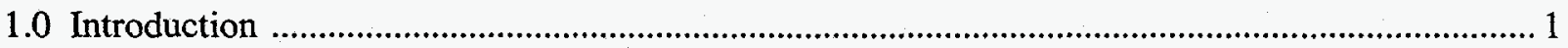

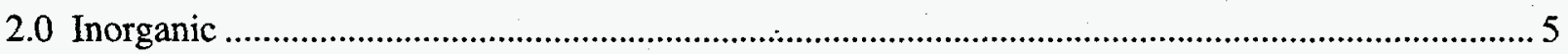

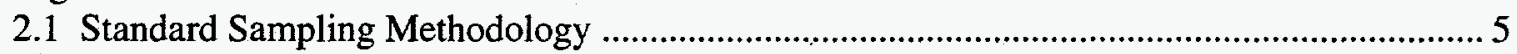

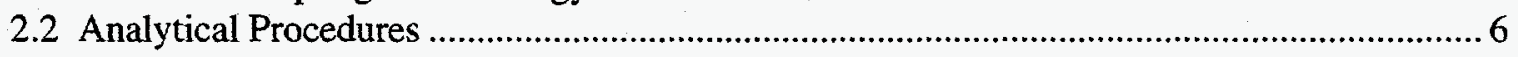

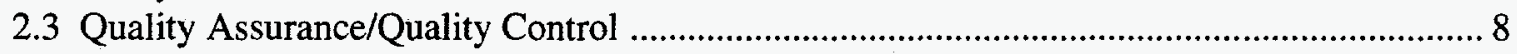

2.4 Inorganic Sample Results ................................................................................................. 9

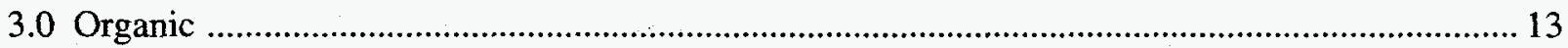

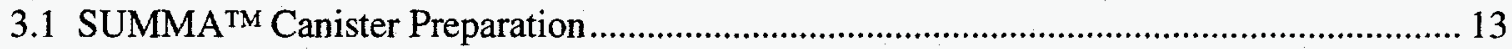

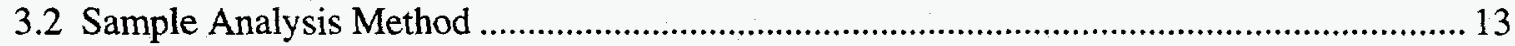

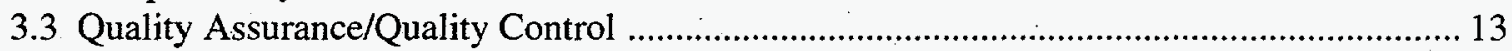

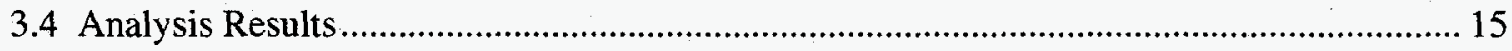

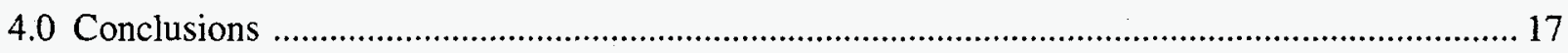

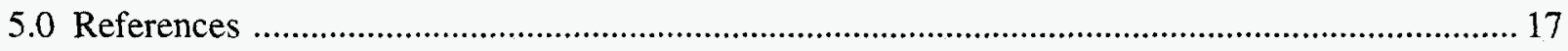

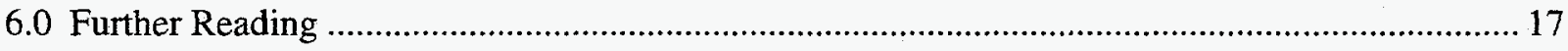

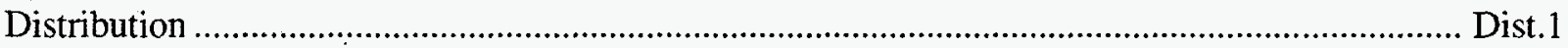




\section{Tables}

2.1 Analysis Procedures and Typical Detection Limits of Target Inorganic Analytes ...................... 8

2.2 List of PNL Inorganic Samples, Blanks, and Gravimetric Results from In Situ Sampling of the Headspace of Tank BY-103 on 5/5/94

2.3 Inorganic Vapor Sample Results Obtained From In Situ Samples Inserted into the Headspace of Tank BY-103 on 5/5/94

3.1 TO-14 Analysis Results for In Situ Samples Collected from the Headspace of Tank BY-103 in SUMMA ${ }^{\mathrm{TM}}$ Canisters on 5/5/94

3.2 Table of Tentatively Identified Compounds and Estimated Concentrations in the Headspace of Tank 241-BY-103 In Situ SUMMA ${ }^{\text {TM }}$ Canister Sample S4026-SUM-079 Collected on 5/5/94

\section{Figures}

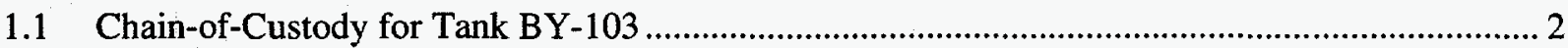

3.1 GC/MS Chromatogram of Hanford Waste Tank BY-103 In Situ SUMMATM

Canister Sample S4026-026-079 Collected on 5/5/94 


\subsection{Introduction}

This report describes results of the analyses of in situ tank-headspace samples taken from the Hanford waste Tank 241-BY-103 (referred to as Tank BY-103). Pacific Northwest Laboratory $(\mathrm{PNL})^{(\mathrm{a})}$ contracted with Westinghouse Hanford Company (WHC) to provide sampling devices and to analyze inorganic and organic analytes collected from the tank headspace. The sample job was designated S4026, and samples were collected by WHC on May 5, 1994, using the in situ sampling system (ISS).

Sampling devices, including six sorbent trains (for inorganic analyses), were supplied to WHC on May 5, 1994. One SUMMA ${ }^{\mathrm{TM}}$ canister (for organic analyses) was supplied to the WHC sampling staff on March 23. Samples were taken (by WHC) from the tank headspace on May 5 and were returned to PNL from the field on May 12. Inorganic (sorbent trap) samples were delivered to PNL on chain of custody (COC)/sample analysis request 006864 . One SUMMA ${ }^{\text {TM }}$ canister was delivered on COC/sample analysis request No. 006854 (see Figure 1).

The samples were inspected upon delivery to the 326/23B laboratory and logged into PNL record book 55408 before implementation of PNL Technical Procedure PNL-TVP-07 ${ }^{(b)}$. Custody of the sorbent traps was transferred to PNL personnel performing the inorganic analysis and stored at refrigerated $\left(\leq 10^{\circ} \mathrm{C}\right)$ temperature until the time of analysis. The canister was stored in the $326 / 23 \mathrm{~B}$ laboratory at ambient $\left(25^{\circ} \mathrm{C}\right)$ temperature until the time of analysis. Access to the $326 / 23 \mathrm{~B}$ laboratory is limited to PNL personnel working on the waste-tank safety program. Analyses described in this report were performed at PNL in the 300 area of the Hanford Reservation. Analytical methods that were used are described in the text. In summary, sorbent traps for inorganic analyses containing sample materials were either weighed (for water analysis) or desorbed with the appropriate aqueous solutions (for $\mathrm{NH}_{3}, \mathrm{NO}_{\mathrm{x}}$, or $\mathrm{HCN}$ analyses). The aqueous extracts were analyzed either by selective electrode or by ion chromatography (IC). Organic analyses were performed using cryogenic preconcentration followed by gas chromatography/mass spectrometry (GC/MS).

(a) Pacific Northwest Laboratory is operated for the U. S. Department of Energy by Battelle Memorial Institute under Contract DE-AC06-76RLO 1830.

(b) PNL-TVP-07, Rev. 0, October 1994, Sample Shipping and Receiving Procedure for PNL Waste Tank Samples, PNL-Technical Procedure, Tank Vapor Project, Richland, Washington. 


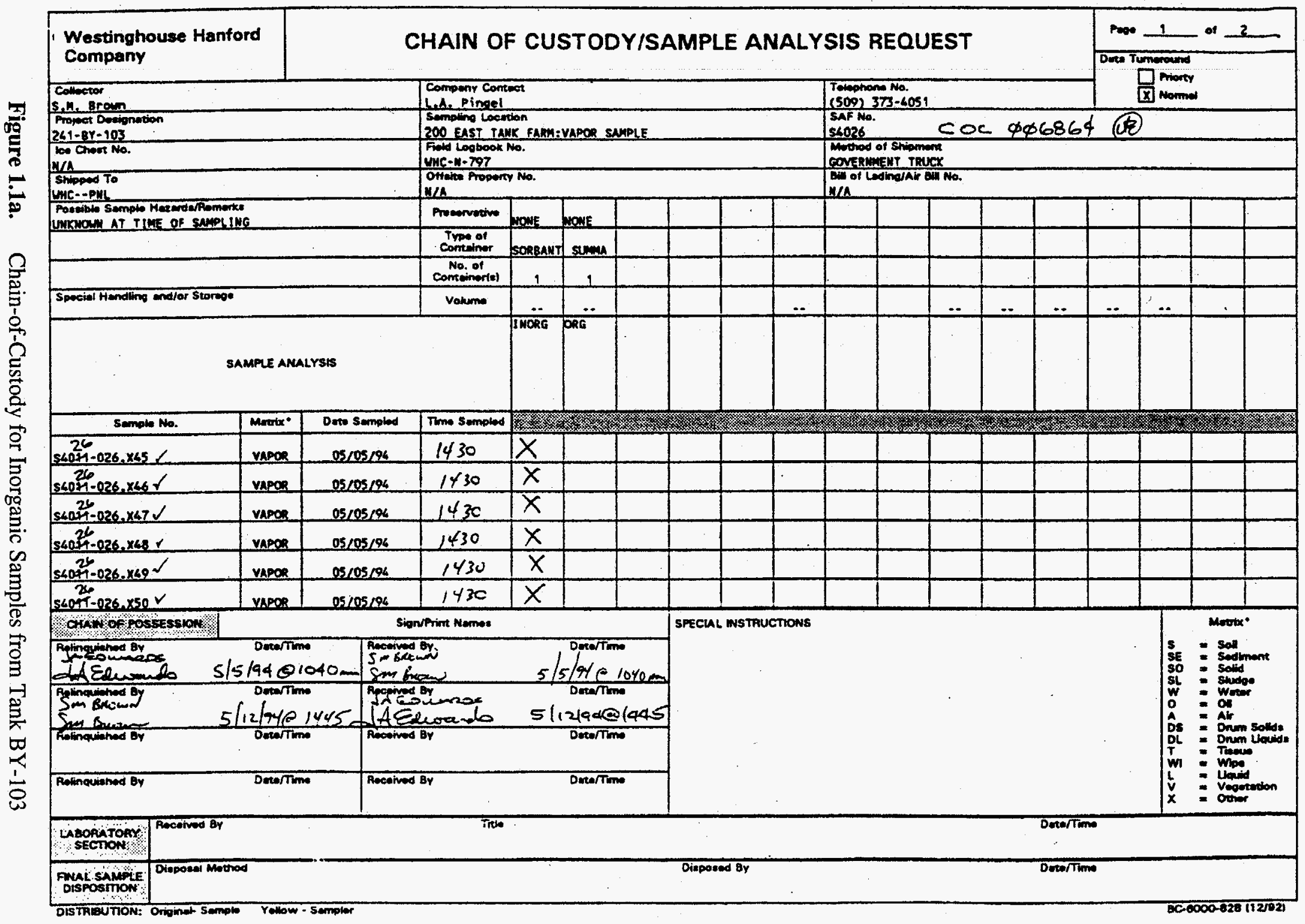




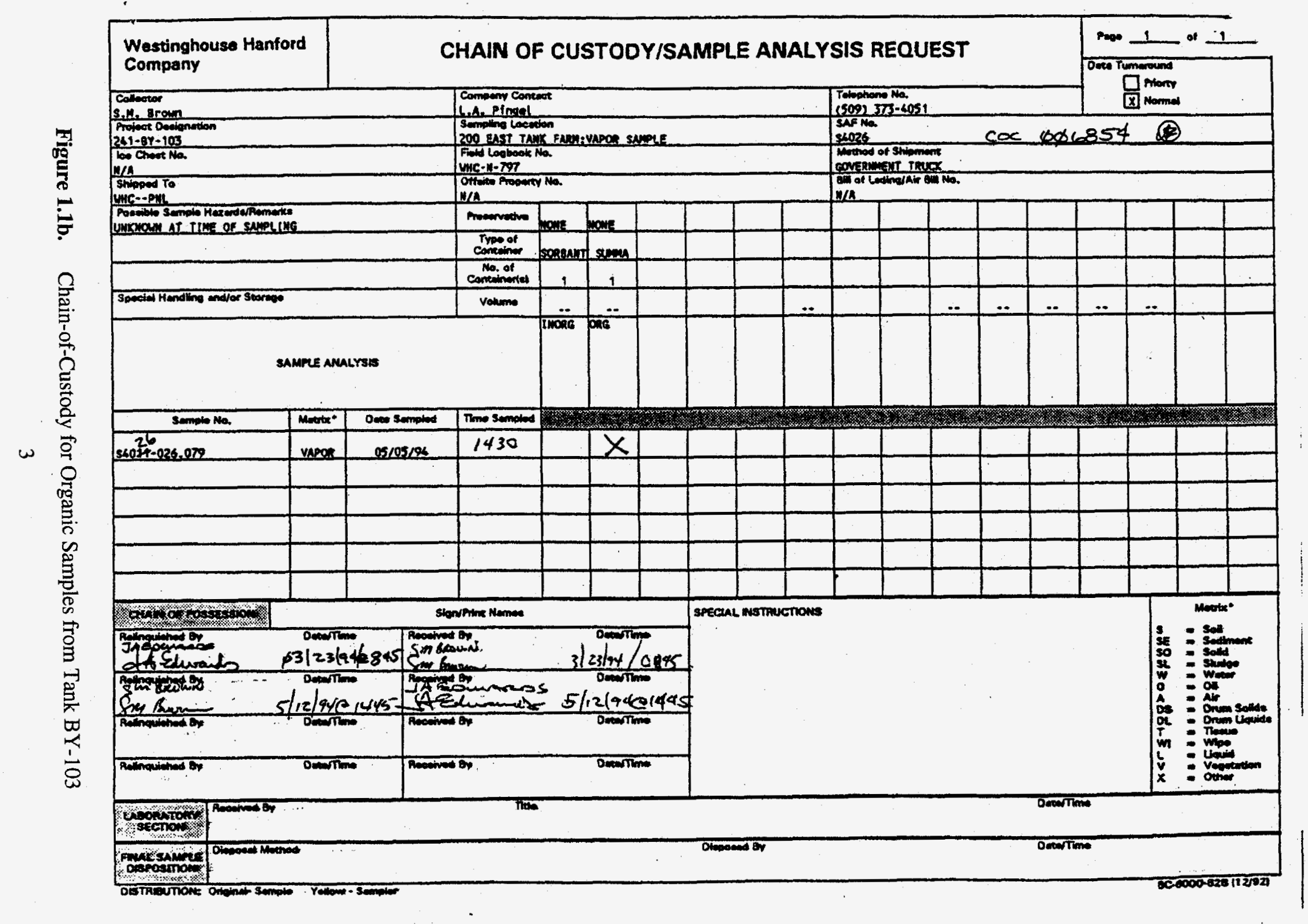





\subsection{Inorganic}

Solid sorbent traps, prepared in sampling trains, were supplied to WHC for sampling the tank headspace. Blanks, spiked blanks (when requested), and exposed samples were returned to PNL for analysis. Analyses were performed to provide information on the tank-headspace concentration of the following analytes: ammonia $\left(\mathrm{NH}_{3}\right)$, nitrogen dioxide $\left(\mathrm{NO}_{2}\right)$, nitric oxide $(\mathrm{NO})$, hydrogen cyanide $(\mathrm{HCN})$, and water. Procedures were similar to those developed previously during sample jobs performed with the vapor sampling system (VSS) connected to the tank headspace of Tank C-103 (Ligotke et al. 1994). Analytical accuracy was estimated based on procedures used. Sample preparation and analyses were performed following PNL quality assurance (QA) impact level (IL) III requirements.

\subsection{Standard Sampling Methodology}

Standard sorbent traps consisting of glass tubes containing sorbent materials to trap the analytes of $\mathrm{NH}_{3}, \mathrm{NO}_{2}, \mathrm{NO}, \mathrm{HCN}$, and $\mathrm{H}_{2} \mathrm{O}$ (SKC Inc., Eighty Four, Pennsylvania) were obtained, prepared, and submitted for use by WHC. The sorbent traps were selected based on their use by the Occupational Safety and Health Administration (OSHA) to perform workplace monitoring, and because of available procedures and verification results associated with that particular application. The typical sorbent traps used consisted of a glass tube containing a sorbent material specific to the compound of interest. In general, the tubes contained two sections; the first section was the primary trap, and the second section provided an indication of breakthrough. In the tubes, sorbent sections are generally held in packed layers separated by glass wool. The sorbent tubes were connected endto-end to prepare multi-trap sorbent trains for sampling.

The type and nominal quantity of sorbent material varied by application. Sorbent traps selected for the tank sample job included the following products. The $\mathrm{NH}_{3}$ sorbent traps contained carbon beads impregnated with sulfuric acid; nominally, $500 \mathrm{mg}$ were contained in the primary and $250 \mathrm{mg}$ in the breakthrough sections. The $\mathrm{NH}_{3}$ was chemisorbed as ammonium sulfate $\left\{\left(\mathrm{NH}_{4}\right)_{2} \mathrm{SO}_{4}\right\}$. The $\mathrm{NO}_{2}$ traps contained a zeolite impregnated with triethanolamine (TEA), with 400 $\mathrm{mg}$ in the primary and $200 \mathrm{mg}$ in the breakthrough sections. The $\mathrm{NO}_{2}$ was absorbed and disproportionated to equi-molar quantities of nitrite ions $\left(\mathrm{NO}_{2}{ }^{-}\right)$and nitrate ions $\left(\mathrm{NO}_{3}{ }^{-}\right)$. Glass tubes containing $800 \mathrm{mg}$ of an oxidant such as chromate were used to convert $\mathrm{NO}$ to $\mathrm{NO}_{2}$. The converted $\mathrm{NO}$ was then collected as nitrite and nitrate in a $\mathrm{NO}_{2}$ trap. The $\mathrm{HCN}$ traps contained soda lime, with $600 \mathrm{mg}$ in the primary and $200 \mathrm{mg}$ in the breakthrough sections. The water traps contained $300 \mathrm{mg}$ of silica gel in the primary and $150 \mathrm{mg}$ in the breakthrough sorbent sections.

Sample materials for inorganic analytes include some or all of the following: samples, spiked samples, spares, blanks, and spiked blanks. The samples of each type were prepared from same-lot batches, with the oxidizer sections of the $\mathrm{NO}_{\mathrm{x}}$ sorbent trains having been stored previously in a freezer. After sample preparation, all samples, spiked samples, blanks, and spiked blanks were stored in a freezer, primarily because of handling recommendations for the oxidizer tubes attached to some samples. After receipt of exposed and radiologically cleared samples from WHC and disassembly of the sorbent trains, samples were provided to the analytical laboratory at ambient temperature, and selected oxidizer sections were returned to a freezer until completion of analyses.

The sorbent traps were prepared in multi-trap sorbent trains configured so sample flow passed in order through the traps, targeting specific analytes, and then through a desiccant trap. The specific 
order of traps within the various sorbent trains is described in section 2.4. The ends of the glass-tube traps were broken, and the traps were weighed and then connected to each other using uniform lengths of 3/8-in. perflouroalkoxy (PFA)-grade Teflon ${ }^{\circledR 0}$ tubing. The tubing was heated in hot air and forced over the open ends of the traps to form a tight seal. Both the inlet and outlet ends of the sorbent trains (the downstream ends of the traps always contained silica gel) were sealed with redplastic end caps provided by the manufacturer. The leading and trailing ends of the sorbent traps remained sealed other than during the actual sampling periods. C-Flex ${ }^{\circledR}$ tubing was provided by WHC to connect the downstream ends of the sorbent trains to the sampling exhaust-manifold connections.

2.1.1 Concentration Calculations. The concentrations of target compounds in the tank headspace were determined from sample results, assuming effective sample transport to the sorbent traps. Concentration, in parts-per-million by volume (ppmv), was determined by dividing the mass of the compound, in $\mu \mathrm{mol}$, by the volume of the dried tank air sampled in mol. The micromolar compound mass was determined by dividing the compound mass, in $\mu \mathrm{g}$, by the molecular weight of the compound, in $\mathrm{g} / \mathrm{mol}$. The molar sample volume was determined, excluding water vapor, by dividing the standard sample volume (at the conditions used by WHC, $21.1^{\circ} \mathrm{C}$ and 760 torr), in $\mathrm{L}$, by 24.1 $\mathrm{L} / \mathrm{mol}$. For example, the concentration $\left(\mathrm{C}_{\mathrm{v}}\right)$ of a $3.00-\mathrm{L}$ sample containing $75.0 \mu \mathrm{g}$ of ammonia equals

$$
\mathrm{C}_{\mathrm{v}}=\frac{75.0 \mu \mathrm{g}}{17 \mathrm{~g} / \mathrm{mol}}\left(\frac{3.00 \mathrm{~L}}{24.1 \mathrm{~L} / \mathrm{mol}}\right)^{-1}=35.4 \mathrm{ppmv}
$$

This calculational method produces concentration results that are slightly conservative (greater than actual) because the volume of water vapor in the sample stream is neglected. The volume of water vapor is not included in the measured sampled volume because of its removal in desiccant traps upstream of the mass flowmeters. However, the bias is generally expected to be small. For a tankheadspace temperature of $35^{\circ} \mathrm{C}$, the magnitude of the bias would be about 1 to $6 \%$, assuming tankheadspace relative humidities of 20 to $100 \%$, respectively. The concentration of mass (determined gravimetrically) was also per dry gas volume at standard conditions.

\subsection{Analytical Procedures}

The compounds of interest were trapped using solid sorbents and chemisorption (adsorption of water vapor). Analytical results were based on extraction and analysis of selected ions. Analytical procedures used are specified herein and compiled in PNL-MA-599.

2.2.1 Ammonia Analysis. The sorbent material from the ammonia-selective sorbent traps was placed into labeled $20-\mathrm{mL}$ glass scintillation vials. Vials containing front-, or primary-, section sorbent material were treated with $10.0 \mathrm{~mL}$ of deionized water (DIW), and vials containing back-upsection sorbent material were treated with $5.0 \mathrm{~mL}$ of DIW. After extraction, the $\mathrm{NH}_{3}$ sorbent traps were analyzed using the selective ion electrode (SIE) procedure PNL-ALO-226 A Ammonia (Nitrogen) in Aqueous Samples\}. Briefly, this method includes 1) preparing a $1000-\mathrm{ppm} \mathrm{NH}_{3}$ stock standard solution from dried reagent-grade $\mathrm{NH}_{4} \mathrm{Cl}$ and DIW on the day analyses are performed;

2) preparing $0.1-, 0.5-, 1.0-, 10-$, and $100-\mathrm{ppm} \mathrm{NH}_{3}$ working calibration standards by serial dilution of the freshly made stock standard; 3 ) generating an initial calibration curve from the measured electromotive force (emf) signal versus $\mathrm{NH}_{3}$ concentration data obtained for the set of working standards; 4) performing a calibration-verification check, using one of the midrange standards, after analyzing every four or five samples; 5) continuing this sequence until all samples of the batch have 
been measured, including duplicates and spiked samples; and 6) remeasuring the complete set of calibration standards at the end of the session. Emf signal measurements obtained for samples are compared to those for standards, either graphically or algebraically (using linear regression) to determine ammonia concentration in the samples.

2.2.2 Nitrite Analysis. The sorbent traps for $\mathrm{NO}_{2}$ and $\mathrm{NO}$ were desorbed in an aqueous TEA and n-butanol solution and analyzed by suppressed-conductivity ion chromatography (SCIC) for nitrite according to PNL-ALO-212, Rev. $1^{(a)}$ and modified to obviate interferences by concentrations of non-target analytes. Specifically, the modifications used were 1) Eluent $1.44 \mathrm{mM} \mathrm{Na} \mathrm{CO}_{3}+1.8 \mathrm{mM}$ $\mathrm{NaHCO}_{3}$ at $2.0 \mathrm{~mL} / \mathrm{min}, 2$ ) one guard column (AG4A) and two separator columns (AS4A) in series instead of just one separator column, and 3) all standards, samples, and blanks injected into the IC sample loop through $0.45-\mu \mathrm{m}$ syringe filters.

For the analysis, the sorbent materials were placed into labeled $20-\mathrm{mL}$ glass scintillation vials. To each vial, $3.0 \mathrm{~mL}$ of desorbing solution $(15 \mathrm{~g} \mathrm{TEA}+1 \mathrm{~mL} \mathrm{~N}$-butanol in $1.0 \mathrm{~L} \mathrm{DIW})$ was added. Primary sorbent-tube sample materials and back-up (breakthrough) sorbent-tube materials were analyzed separately using identical procedures. Each analytical session was conducted as follows. Working nitrite standards $(0,0.1,0.25$, and $0.5 \mathrm{ppm})$ were prepared by diluting a stock nitrite standard with desorbing solution. An initial calibration curve was prepared from the instrument response (chromatographic peak height) versus nitrite standard concentration data for the set of working standards. A calibration verification check using one of the midrange standards was performed after the analysis of every six samples. If the instrument response indicated that sample nitrite concentration was outside the calibration range ( $>0.5 \mathrm{ppm}$ nitrite), the sample was diluted with desorbing solution and reanalyzed. After all samples of a batch were analyzed, the complete set of calibration standards was remeasured to verify consistent instrument response, and the analytical session was terminated.

Instrument responses (peak height) observed for samples were compared to those for standards to determine the nitrite concentration of the samples. Because $\mathrm{NO}_{2}$ and $\mathrm{NO}$ converted to $\mathrm{NO}_{2}$ were collected on the sorbent as equal quantities of nitrite and nitrate, and the analysis was specific for nitrite, the molar masses of $\mathrm{NO}_{2}$ and $\mathrm{NO}$ were determined by doubling the analytically determined molar mass of nitrite.

2.2.3 Cyanide Analysis. The HCN samples were desorbed in $3.0 \mathrm{~mL}$ of $0.02 \mathrm{~N}$ sodium hydroxide and analyzed by amperometric detection ion chromatography according to PNL-ALO-271(b). Calibration standards, typically $0,20,50$, and $100 \mathrm{ppb} \mathrm{CN}^{-}$, were prepared from a stock 1000 -ppm $\mathrm{CN}^{-}$standard on the day of sample analysis in $0.02 \mathrm{~N} \mathrm{NaOH}$ matrix. The same analysis sequence described above in the "nitrite analysis" section was used. Instrument responses (peak height) observed for the samples were compared to those for standards to determine $\mathrm{CN}^{-}$the concentration of the samples.

2.2.4 Mass (Water) Analysis. Sorbent traps used to make each sample train were weighed using a semi-micro mass balance, after labeling and breaking the glass tube ends, without plastic end caps. After receipt of exposed samples, the sorbent traps were again weighed to determine the change in mass. Records of the measurements were documented on sample-preparation data sheets. The mass

\footnotetext{
(a) Pacific Northwest Laboratory. Determination of Inorganic Anions by Ion Chromatography, Richland Washington.

(b) Pacific Northwest Laboratory. Procedure for Analysis of Free cyanide in Water and Soil Sample Leachates, Richland Washington.
} 
concentration, generally roughly equal to the concentration of water, was determined by dividing the combined change in mass from all traps in a sorbent train by the actual volume of gas sampled. Blanks and spiked blanks were included to provide information on uncertainty.

\subsection{Quality Assurance/Quality Control}

Analytical work was performed according to quality levels identified in the project QA plan and several PNL documents. The samples were analyzed following PNL IL III. The PNL documents include some or all of the following: PNL-MA-70 (Part 2), PNL-MA-599, PNL-ALO-212, PNLALO-226, PNL-ALO-271, and MCS-033. A summary of the analysis procedures and limits for the target inorganic compounds is provided in Table 2.1. From the table, it can be seen that the minimum detection limit (MDL) required to resolve the analyte at one-tenth of the recommended exposure limit (REL) for each of the target analytes is achieved using current procedures and with a vapor-sample volume of $3 \mathrm{~L}$ and a desorption-solution volume of $3 \mathrm{~mL}$ (10 mL for ammonia).

Table 2.1. Analysis Procedures and Typical Detection Limits of Target Inorganic Analytes. Not all analytes are included in every sample job.

\begin{tabular}{|c|c|c|c|c|c|}
\hline Analyte & Formula & Procedure & $\begin{array}{l}\mathrm{REL}^{(\mathrm{a})} \\
\text { (ppmv) }\end{array}$ & $\begin{array}{c}0.1 \times \mathrm{REL}^{(a)} \\
(\mathrm{ppmv})\end{array}$ & $\begin{array}{l}\mathrm{MDL}^{(b)} \\
\text { (ppmv) }\end{array}$ \\
\hline Ammonia & $\mathrm{NH}_{3}$ & PNL-ALO-226 & 25 & 2.5 & 0.5 \\
\hline Nitrogen dioxide & $\mathrm{NO}_{2}$ & PNL-ALO-212 & 1 & 0.1 & 0.02 \\
\hline Nitric oxide & $\mathrm{NO}^{2}$ & PNL-ALO-212 & 25 & 2.5 & 0.02 \\
\hline Sulfur oxide & $\mathrm{SO}_{\mathrm{x}}$ & PNL-ALO-212 & 2 & 0.2 & 00.2 \\
\hline Hydrogen cyanide & $\mathrm{HCN}$ & PNL-ALO-271 & 4.8 & 0.48 & 0.01 \\
\hline Mass (water) ${ }^{(c)}$ & $\mathrm{n} / \mathrm{a}$ & $\mathrm{n} / \mathrm{a}$ & $\mathrm{n} / \mathrm{a}$ & $\mathrm{n} / \mathrm{a}$ & $\mathrm{n} / \mathrm{a}$ \\
\hline
\end{tabular}

(a) Target analytical limits are equal to one-tenth of the REL.

(b) MDL is defined as the vapor concentration that can be detected with an uncertainty equal to about the magnitude of the measurement. The uncertainty is expected to reduce to about onequarter of the magnitude of the measurement at a concentration of four times the MDL. The MDLs were based on the assumption that $3 \mathrm{~L}$ of vapor are sampled; if greater volumes of vapor are sampled, correspondingly smaller MDLs can be achieved. The MDLs were also based on desorbing-solution volumes of $10 \mathrm{~mL}$ for ammonia and $3 \mathrm{~mL}$ for the other analytes.

(c) The vapor mass concentration, thought to be largely water vapor, is determined for estimates of humidity.

The accuracy of concentration measurements depends on errors associated with both sampling and analysis (see Section 2.4). Sampling information, including sample volumes, was provided by WHC; sample volume uncertainty was not provided. The accuracy of analytical results depends on the method used. For ammonia analyses, the accuracy of laboratory measurements by SIE was estimated to be $\pm 5 \%$ relative, independent of concentration at $1 \mu \mathrm{g} / \mathrm{mL}$ or greater levels. The uncertainty includes preparation of standards, purity of the ammonium salt used to prepare standards, potential operator bias, ambient temperature variations, etc. Unfortunately, no known National Institute for Standards and Technology (NIST)-traceable standard reference material (SRM) is available against which to compare working standards. As for ammonia, no known NIST SRM is available for nitrite analysis (for $\mathrm{NO}_{2}$ and $\mathrm{NO}$ ). Based on experience in comparing nitrite working standards prepared from several different sources and factors mentioned for ammonia above, the estimated maximum bias for samples derived from sampling for $\mathrm{NO}_{2}$ is $\pm 10 \%$, and for samples 
derived from sampling for $\mathrm{NO}$, it is $\pm 5 \%$ relative. For $\mathrm{SO}_{\mathrm{x}}$ analysis, the IC determination of sulfate derived from $\mathrm{SO}_{\mathrm{x}}$ trapped in sorbent traps is judged to be biased no more than $10 \%$ even at the very low concentrations of solutions actually analyzed. Comparison of working standards to an NIST standard reference material (SRM) solution for sulfate exhibit no more than a 2 to $3 \%$ difference at concentrations of $2 \mathrm{ppm}$ or greater. For HCN analyses, an NIST SRM for uncompelxed cyanide is not available. The estimated bias (accuracy) of the free cyanide measurements is no more than $5 \%$ relative for normal working range (which encompasses the concentration levels encountered in blanks and samples derived from sorbent-trap leachates). The accuracy of measurements of sample mass is $\pm 0.05 \mathrm{mg}$, or much less than $1 \%$ of the mass changes of samples, and roughly $5 \%$ or less of the mass change of blanks.

\subsection{Inorganic Sample Results}

Sorbent-trap trains and controls were prepared on 3/28/94 and submitted to WHC. They were used by WHC to sample the tank headspace of Tank BY-103 on 5/5/94 using the ISS. The sample job designation number was S4026. The exposed samples were returned to PNL on 5/12/94 and subsequently analyzed on 6/8/94 $\left(\mathrm{H}_{2} \mathrm{O}\right), 6 / 14 / 94\left(\mathrm{NH}_{3}\right.$ and $\left.\mathrm{HCN}\right)$, and $7 / 1 / 94\left(\mathrm{NO}_{\mathrm{x}}\right)$ to provide information on the tank-headspace concentrations of selected inorganic compounds. Sampling and analysis for sulfur oxides were not requested. Blank and spiked-blank samples associated with this sample job were those sent for the related ISS sample job in Tank BY-111 (S4028) or related sample jobs. The sample volume information for the current sample job was received from WHC on 8/2/94.

A list of samples, sampling information, sample volumes, and gravimetric results is shown in Table 2.2. The types of sample trains used and the order of sorbent traps within each train are also shown in the table. For example, the sorbent train $\mathrm{NH}_{3} / \mathrm{NO}_{\mathrm{x}} / \mathrm{H}_{2} \mathrm{O}$ contained an ammonia trap at the inlet end, a $\mathrm{NO}_{\mathrm{x}}$ series in the middle (section 2.4.2), and a desiccant trap at the outlet end. Analytical mass and concentration results are shown in Table 2.3. Sample volumes were provided by WHC; sample-volume uncertainty was not provided. Tank-headspace concentration results (Table 2.3) are based on this information, and the listed uncertainties equal plus-or-minus one standard deviation of the individual results from each set of samples. Where analytical results from samples were nearly indistinguishable from those of blanks, indicating very low tank-headspace concentrations of the analyte, the concentration results (Table 2.3) are listed as "less-than-or-equal-to" a probable maximum value determined by subtracting the average of the blanks less one standard deviation from the average of the samples plus one standard deviation. Results of control samples, such as spiked blanks, are discussed in this section. Spiked blanks, when used, were transported to the field but not opened. Spiked samples, when used, were opened in the field and used to collect tank-headspace gas. Sample results were not corrected for the percentage recoveries of spiked blanks.

2.4.1 Ammonia Results. The concentration of $\mathrm{NH}_{3}$ was $30.7 \pm 0.4 \mathrm{ppmv}$, based on all three samples. The blank-corrected $\mathrm{NH}_{3}$ quantities in the sorbent traps ranged from 5.2 to $5.8 \mu \mathrm{mol}$ with no indication of breakthrough. Blank corrections, $\leq 0.06 \mu \mathrm{mol}$ in front and $\leq 0.03 \mu \mathrm{mol}$ in back sorbent sections (Clauss et al. 1994), were not significant $(<2 \%)$. Although spiked blanks were not tested, the percentage recoveries of three sets of blanks spiked with $12.2,22.3$, and $46.4 \mu \mathrm{mol} \mathrm{NH_{3 }}$ were $101 \pm 4 \%, 109 \pm 2 \%$, and $104 \pm 1 \%$, respectively, during related sample jobs (Clauss et al. 1994; Ligotke et al. 1994). The analysis of one sample was duplicated and yielded a repeatability of $\pm 2 \%$. One sample leachate was spiked after initial analysis with 2.5 times the mass of $\mathrm{NH}_{3}$ in the sample and yielded a percentage recovery of $96 \%$. A 5-point calibration was performed over an $\mathrm{NH}_{3}$ range of 0.1 to $1000 \mu \mathrm{g} / \mathrm{mL}$. Minor differences between the individual results of the three $\mathrm{NH}_{3}$ samples matched closely the differences in the quantities of dry air sampled during each sample. 
Table 2.2. List of PNL Inorganic Samples, Blanks, and Gravimetric Results From In Situ Sampling of the Headspace of Tank BY-103 on 5/5/94

\begin{tabular}{|c|c|c|c|c|c|}
\hline Sample Number & Sorbent Train Type & $\begin{array}{l}\text { Sample } \\
\text { Flow Rate } \\
\text { (mL/min) }\end{array}$ & $\begin{array}{c}\text { Duration } \\
\text { (min) }\end{array}$ & $\begin{array}{c}\text { Sample } \\
\text { Volume } \\
\text { (L) } \\
\end{array}$ & $\begin{array}{r}\text { Mass } \\
\text { Gain } \\
(\mathrm{g}) \\
\end{array}$ \\
\hline $\mathrm{S} 4026-026-\mathrm{X} 48$ & $\mathrm{NH}_{3} / \mathrm{NO}_{\mathrm{x}} / \mathrm{H}_{2} \mathrm{O}$ Sample & 285 & 15.0 & 4.28 & $N^{(b)}$ \\
\hline S4026-026-X49 & $\mathrm{NH}_{3} / \mathrm{NO}_{x} / \mathrm{H}_{2} \mathrm{O}$ Sample & 277 & 15.0 & 4.15 & NA \\
\hline $\mathrm{S} 4026-\mathrm{S} 026-\mathrm{X} 50$ & $\mathrm{NH}_{3} / \mathrm{NO}_{\mathrm{x}} / \mathrm{H}_{2} \mathrm{O}$ Sample & 308 & 15.0 & 4.62 & NA \\
\hline S4026-026-X45 & $\mathrm{HCN} / \mathrm{H}_{2} \mathrm{O}$ Sample & 279 & 15.0 & 4.19 & 0.0405 \\
\hline S4026-026-X46 & $\mathrm{HCN} / \mathrm{H}_{2} \mathrm{O}$ Sample & 286 & 15.0 & 4.28 & 0.0371 \\
\hline S4026-026-X47 & $\mathrm{HCN} / \mathrm{H}_{2} \mathrm{O}$ Sample & 241 & 15.0 & 3.61 & 0.0391 \\
\hline S4028-028-X66 & $\mathrm{HCN} / \mathrm{H}_{2} \mathrm{O}$ Blank (BY-111) & $\mathrm{n} / \mathrm{a}$ & $\mathrm{n} / \mathrm{a}$ & $\mathrm{n} / \mathrm{a}$ & 0.0031 \\
\hline S4028-028-X67 & $\mathrm{HCN} / \mathrm{H}_{2} \mathrm{O}$ Blank (BY-111) & $\mathrm{n} / \mathrm{a}$ & $\mathrm{n} / \mathrm{a}$ & $\mathrm{n} / \mathrm{a}$ & 0.0033 \\
\hline S4028-028-X68 & $\mathrm{HCN} / \mathrm{H}_{2} \mathrm{O}$ Blank (BY-111) & $\mathrm{n} / \mathrm{a}$ & $\mathrm{n} / \mathrm{a}$ & $\mathrm{n} / \mathrm{a}$ & 0.0033 \\
\hline
\end{tabular}

(a) Sampling information and dry-gas sample volumes, corrected to $21^{\circ} \mathrm{C}$ and 760 torr, were provided by WHC. Uncertainty values were not provided with sample volume results.

(b) NA = not analyzed. Only selected back sorbent sections were analyzed; $\mathrm{n} / \mathrm{a}=$ not applicable.

2.4.2 Nitrogen Oxides Results. Measurements of $\mathrm{NO}_{2}$ and $\mathrm{NO}$ were made using three 5-segment $\mathrm{NH}_{3} / \mathrm{NO}_{\mathrm{x}} / \mathrm{H}_{2} \mathrm{O}$ sorbent-trap trains (the $\mathrm{NO}_{\mathrm{x}}$ trains consisted of $\mathrm{NO}_{2}$ trap, oxidizer, $\mathrm{NO}_{2}$ trap). Related sample jobs, performed using the VSS in BY-104, -105, and -106 both with and without $\mathrm{NO}_{\mathrm{x}}$ trains protected by a leading $\mathrm{NH}_{3}$ trap (e.g., Clauss et al. 1994), indicated that the presence of the upstream $\mathrm{NH}_{3}$ traps resulted in $\mathrm{NO}$ concentrations that were about 1.3- to 1.6-fold less than those from unprotected $\mathrm{NO}_{2}$ traps. The $\mathrm{NO}_{2}$ concentrations were also potentially less following an $\mathrm{NH}_{3}$ trap.

The concentrations of $\mathrm{NO}_{2}$ and $\mathrm{NO}$ were $\leq 0.1$ and $\leq 0.2 \mathrm{ppmv}$, respectively. The concentrations exceeded the usual MDL (Table 2.1) for the analytes largely because of a lack of detailed blank information. Blank-corrected $\mathrm{NO}_{2}^{-}$quantities in the sorbent traps averaged $\leq 0.0085$ $\mu \mathrm{mol}\left(\mathrm{NO}_{2}\right.$ samples) and $\leq 0.014 \mu \mathrm{mol}$ (NO samples). Nitrite blank levels used to correct data were $0.016 \pm 0.002 \mu \mathrm{mol}$ in front and $0.0087 \pm 0.0007 \mu \mathrm{mol}$ in back sorbent sections, and were based on typical values such as those reported by Clauss et al. (1994). Although spiked blanks were not tested, blanks spiked with $0.0064,0.047,0.11$, and $0.74 \mu \mathrm{mol} \mathrm{NO}_{2}^{-}$during a related sample job yielded percentage recoveries of $153 \pm 14 \%, 103 \pm 4 \%, 106 \pm 8 \%$, and $111 \pm 7 \%$, respectively (Ligotke et al. 1994; Clauss et al. 1994). No samples were reanalyzed to check repeatability. No sample leachates were spiked after initial analysis with quantities of $\mathrm{NO}_{2}{ }^{-}$to test analytical percentage recoveries. A 4-point calibration was performed over a concentration range of 0 to $0.5 \mu \mathrm{g} \mathrm{NO}_{2}^{-}$per $\mathrm{mL}$ in the desorbing matrix.

2.4.3 Hydrogen Cyanide Results. The concentration of $\mathrm{HCN}$ was $\leq 0.005 \mathrm{ppmv}$, based on all three samples. Blank-corrected sample results averaged $\leq 0.0009 \mu \mathrm{mol}$. Blank corrections were based on the results of three blanks from a related sample job (Tank BY-111) which averaged 0.0128 $\pm 0.0005 \mu \mathrm{mol}$ for the front and $0.0049 \pm 0.0002 \mu \mathrm{mol}$ for the back sorbent section. Three spikedblank sorbent traps were prepared by adding $50 \mu \mathrm{L}$ of 5 -ppm $\mathrm{CN}^{-}$in water, confirmed 
Table 2.3. Inorganic Vapor Sample Results Obtained from In Situ Samples Inserted into the Headspace of Tank BY-103 on 5/5/94

\begin{tabular}{|c|c|c|c|c|c|}
\hline \multirow[b]{2}{*}{ Sample } & \multicolumn{3}{|c|}{ Analytical Results ( $\mu \mathrm{mol})$} & \multirow{2}{*}{$\begin{array}{l}\text { Sample } \\
\text { Volume } \\
\text { (L) }\end{array}$} & \multirow{2}{*}{$\begin{array}{c}\text { Vapor (a) } \\
\text { Concentration } \\
\text { (ppmv) } \\
\end{array}$} \\
\hline & $\begin{array}{l}\text { Front } \\
\text { Section }\end{array}$ & $\begin{array}{l}\text { Back } \\
\text { Section }\end{array}$ & $\begin{array}{c}\text { Total }^{(\mathbf{b})} \\
\text { Blank-Corrected }\end{array}$ & & \\
\hline$\underline{\mathrm{NH}}_{3}$ Samples: & & & $\underline{5.54}^{(\mathrm{c})}$ & $\underline{4.35}^{(\mathrm{c})}$ & $30.7 \pm 0.4^{(c)}$ \\
\hline S4026-026-X48 & 5.6 & $\mathrm{NA}^{(\mathrm{d})}$ & 5.5 & 4.28 & 31.2 \\
\hline S4026-026-X49 & 5.3 & NA & 5.2 & 4.15 & 30.5 \\
\hline S4026-026-X50 & 5.9 & $\leq 0.03$ & 5.8 & 4.62 & 30.5 \\
\hline$\underline{\mathrm{NO}}_{2}$ Samples: & & & $\leqq 0.0085$ & $\underline{4.35}$ & $\leqq 0.1$ \\
\hline $\mathrm{S} 4026-026-\mathrm{X} 48$ & 0.0156 & 0.0079 & $n / a$ & 4.28 & $\mathrm{n} / \mathrm{a}$ \\
\hline S4026-026-X49 & 0.0210 & 0.0076 & n/a & 4.15 & $\mathrm{n} / \mathrm{a}$ \\
\hline $\mathrm{S} 4026-026-\mathrm{X} 50$ & 0.0181 & 0.0098 & $n / a$ & 4.62 & $\mathrm{n} / \mathrm{a}$ \\
\hline NO Samples: & & & $\leqq 0.014$ & $\underline{4.35}$ & $\leqq 0.2$ \\
\hline S4026-026-X48 & 0.0211 & 0.0076 & n/a & 4.28 & $\mathrm{n} / \mathrm{a}$ \\
\hline S4026-026-X49 & 0.0208 & 0.0094 & $\mathrm{n} / \mathrm{a}$ & 4.15 & $\mathrm{n} / \mathrm{a}$ \\
\hline S4026-026-X50 & 0.0272 & 0.0090 & $\mathrm{n} / \mathrm{a}$ & 4.62 & $\mathrm{n} / \mathrm{a}$ \\
\hline HCN Samples: & & & $\leqq 0.0009$ & $\underline{4.03}$ & $\leqq 0.005$ \\
\hline S4026-026-X45 & 0.0130 & 0.0047 & $n / a$ & 4.19 & $\mathrm{n} / \mathrm{a}$ \\
\hline S4026-026-X46 & 0.0120 & 0.0046 & $\mathrm{n} / \mathrm{a}$ & 4.28 & $n / a$ \\
\hline$S 4026-026-X 47$ & 0.0123 & 0.0046 & $\mathrm{n} / \mathrm{a}$ & 3.61 & $\mathrm{n} / \mathrm{a}$ \\
\hline Gravimetric Samples (1 & $\mathrm{g} / \mathrm{L}):$ & & $35.7 \mathrm{mg}$ & $\underline{4.03}$ & $\underline{8.9 \pm 1.0 \mathrm{mg} / \mathrm{L}}$ \\
\hline S4026-026-X45 & $\mathrm{n} / \mathrm{a}$ & $\mathrm{n} / \mathrm{a}$ & 37.3 & 4.19 & 8.90 \\
\hline S4026-026-X46 & $n / a$ & $\mathrm{n} / \mathrm{a}$ & 33.9 & 4.28 & 7.92 \\
\hline S4026-026-X47 & $n / a$ & $\mathrm{n} / \mathrm{a}$ & 35.9 & 3.61 & 9.94 \\
\hline
\end{tabular}

(a) Blank-corrected vapor concentrations were calculated using WHC-reported air sample volumes (corrected to $21^{\circ} \mathrm{C}$ and 760 torr). In the calculation for concentration, the nitrite values (listed) were doubled to account for unanalyzed nitrate. Sample results were not corrected for percentage recovery of spiked samples or spiked blanks.

(b) Total blank-corrected analyte masses were determined, when significant, by subtracting the quantity of analyte found in blanks from that found in samples. The levels of analytes found in blanks are described in section 2.4 .

(c) Underlined values represent the average of the set of samples. Concentration uncertainty equals \pm 1 standard deviation (absolute) for each set of samples. The use of "S" is defined in section 2.0.

(d) $\mathrm{NA}=$ not analyzed. Only selected back sorbent sections were analyzed. $\mathrm{n} / \mathrm{a}=$ not applicable.

gravimetrically to average $0.0099 \pm 0.0001 \mu \mathrm{mol} \mathrm{CN}-$ \{e.g., $0.0520 \mathrm{~g} \mathrm{x} 1.00 \mathrm{~mL} / \mathrm{g} \times 5.00 \mu \mathrm{g} \mathrm{CN}-/ \mathrm{mL}$ $\div 26 \mathrm{~g} / \mathrm{mol}=0.0100 \mu \mathrm{mol}\}$, and sent to WHC with samples for a related job in Tank BY-111. The spikes, sample numbers $\$ 4028-S O R-X 66,-X 67$, and -X68, were applied to the center of front sorbent sections, and levels of $\mathrm{CN}^{-}$in the back sections were equal to blank levels which indicated that no migration of $\mathrm{CN}^{-}$occurred. The spiked blanks were analyzed and yielded an average blankcorrected percentage recovery of $69 \pm 10 \%$ after a hold time of 11 weeks. It is possible that the poor spike recovery was related to the relatively long hold time. No samples were reanalyzed to check 
repeatability. No sample leachates were spiked after initial analysis with quantities of $\mathrm{CN}^{-}$to test analytical percentage recoveries.

2.4.4 Gravimetric Results. The mass concentration of material collected in the sorbent-trap trains, believed to be primarily water vapor, was $8.9 \pm 1.0 \mathrm{mg} / \mathrm{L}$. The result was based on an average mass gain of $0.036 \pm 0.002 \mathrm{~g}$ from three of three sets of $\mathrm{HCN} / \mathrm{H}_{2} \mathrm{O}$ sample trains. The $\mathrm{NH}_{3} / \mathrm{NO}_{2} / \mathrm{H}_{2} \mathrm{O}$ sample trains were not weighed. Blank corrections for the weighed sample trains were $0.0032 \pm$ $0.0001 \mathrm{~g}$, based on the results of three blank sorbent trains sent to WHC with samples for Tank BY111. Although no spiked blanks were tested, the percentage recovery of mass from three blank $\mathrm{H}_{2} \mathrm{O}$ traps spiked with $51 \mathrm{mg}$ water was $103 \pm 2 \%$ during a related sample job (Clauss et al. 1994). 


\subsection{Organic}

\subsection{SUMMA ${ }^{\mathrm{TM}}$ Canister Preparation}

Before sending SUMMA ${ }^{\mathrm{TM}}$ canisters out to the field for sampling, the canisters are cleaned and verified contaminant free according to PNL Technical Procedure PNL-TVP-02(a). The cleaning procedure uses an EnTech 3000 cleaning system that controls 1) filling the canisters with purified humid air and 2) evacuating, for several cycles with applied heat, before allowing the canister to evacuate overnight. The canister is filled a final time with purified humid air for analysis by PNL Technical Procedure PNL-TVP-01(b), which is a modification of U.S. Environmental Protection Agency (EPA) Compendium Method TO-14. If the canister is verified as clean, free of TO-14 contaminants to a level of $5 \mathrm{ppbv}$, the canister is evacuated to $30 \mathrm{in}$. $\mathrm{Hg}$, tagged, and stored for use in the field. Before sending the canisters out to the field for sampling, the canisters are prehumidified with $100 \mu \mathrm{L}$ of distilled water and labeled with a field-sampling identification. Canisters not used after 30 days of storage are recleaned and validated before use.

\subsection{Sample Analysis Method}

The SUMMA ${ }^{\mathrm{TM}}$ canister sample was analyzed according to PNL Technical Procedure PNLTVP-03(c), which is a modified version of EPA compendium Method TO-14. The method uses an EnTech cryoconcentration system interfaced with a Hewlett Packard (HP) 5971 GC/MS. The EnTech concentrator is used to pull a metered volume of sample air from the SUMMA ${ }^{\mathrm{TM}}$ canister, cryogenically concentrate the air volume, then transfer the volume to the GC/MS for analysis. A 100$\mathrm{mL}$ volume of sample is measured and analyzed from the tank headspace. The organic components in the sampled air are separated on an analytical column, J\&W Scientific DB-1 phase, $60-\mathrm{m}$ by $0.32-$ $\mathrm{mm}$ internal diameter with $3-\mu \mathrm{m}$ film thickness. The $\mathrm{GC}$ oven is programmed to run a temperature gradient beginning at $40^{\circ} \mathrm{C}$, holding for $5 \mathrm{~min}$, and ramping at $4^{\circ} \mathrm{C}$ per min to a final temperature of $260^{\circ} \mathrm{C}$, with a 5 -min hold.

\subsection{Quality Assurance/Quality Control}

Before the tank sample was analyzed, a diagnostic check was performed on the GC/MS instrument by running an instrument "quick tune," as described in PNL-TVP-03. Upon satisfactory completion of the instrument diagnostic check, a blank volume of purified nitrogen was analyzed to check the cleanliness of the system. The instrument was then calibrated over 6 data points ranging from $2 \mathrm{ppbv}$ to $100 \mathrm{ppbv}$, using a standard gas mixture containing 40 volatile organic compounds listed in EPA compendium Method TO-14. A gas mixture containing bromochloromethane, 1,4difluorobenzene, and chlorobenzene- $\mathrm{d}_{5}$ was used as an internal standard (IS) for all blank, calibration

(a) Pacific Northwest Laboratory. 8/94. Cleaning SUMMA ${ }^{\mathrm{TM}}$ Canisters and the Validation of the Cleaning Process, PNL-TVP-02 (Rev. 0), PNL Technical Procedure, Richland, Washington.

(b) Pacific Northwest Laboratory. 8/94. Determination of TO-14 Volatile Organic Compounds in Ambient Air Using SUMMATM Passivated Canister Sampling and Gas Chromatographic-Mass Spectrometric Analysis, PNL-TVP-01 (Rev. 0). PNL Technical Procedure, Richland, Washington.

(c) Pacific Northwest Laboratory. Determination of TO-14 Volatile Organic Compounds in Hanford Waste Tank Headspace Samples Using SUMMATM Passivated Canister Sampling and Gas ChromatographicMass Spectrometry Analysis, PNL-TVP-03. PNL Technical Procedure, Richland, Washington. 
standard, and sample analyses. Analyte response from sample components, ISs, and standards were obtained from the extracted ion plot from their selected mass ion. The calibration curve was generated by calculating the relative response ratios of the IS to calibration standard responses and plotting the ratios against the ratio of the calibration-standard concentration (in ppbv) to the IS concentration. A least-squares linear-regression routine was applied to the data set to generate the best-fit line for each compound. The equation for that line was then used to quantify the TO-14 compounds found in the tank samples.

3.3.1 Quantitation of TO-14 Results. The quantitative-analysis results for the TO-14 volatile organic compounds were calculated directly from the calibration curve generated using the IS method described above and in PNL-TVP-03. The conversion from ppmv to $\mathrm{mg} / \mathrm{m}^{3}$ assumes standard temperature and pressure (STP) conditions of 760 Torr and $273^{\circ} \mathrm{K}$ and was calculated directly from the following equation:

$$
\mathrm{mg} / \mathrm{m}^{3}=\frac{\mathrm{ppmv} \times \mathrm{g} \mathrm{mol} \mathrm{wt} \mathrm{of} \mathrm{compound}}{22.4 \mathrm{~L} / \mathrm{mol}}
$$

3.3.2 Identification and Quantitation of Tentatively Identified Compounds. The tentatively identified compounds (TICs) are determined by mass-spectral interpretation and comparison of the spectra with the EPA/NIST/WILEY Library, which is a part of the HP 5971 instrument operating system. Chromatographic peaks with an area count greater than, or equal to, one half of the total area count of the chlorobenzene- $\mathrm{d}_{5}$ IS peak at the 20 -ppbv calibration level are tentatively identified and quantitatively estimated. This standard was chosen to determine the integration cutoff as it is in the middle of the chromatographic range and not in a region typically affected by coelution of other compounds. The quality of the mass-spectral searches was then reviewed by the principal investigators before the identification was assigned to each chromatographic peak.

The concentration of each TIC was estimated using a relative response factor calculated using a corrected total peak area for the IS chlorobenzene- $d_{5}$. Specifically, the total integrated area for the chlorobenzene- $d_{5}$ peak had to be corrected for possible coeluting compounds before calculating the response factor. The corrected total peak area for the IS was calculated by multiplying the IS quantitation ion by a correction factor based on the ratio of the total integrated peak area to the quantitation ion as measured in blank runs. The corrected peak area was then used to calculate a response factor using the IS concentration in $\mathrm{mg} / \mathrm{m}^{3}$ :

$$
\text { Response Factor }=\frac{\text { IS conc. }\left(\mathrm{mg} / \mathrm{m}^{3}\right)}{\text { IS peak area }}
$$

The calculated response factor was then multiplied by the TIC peak area to give an estimated concentration for that compound. For butane, the total peak area was multiplied by the response factor for chlorobenzene- $\mathrm{d}_{5}$ to give an estimated concentration of $1.26 \mathrm{mg} / \mathrm{m}^{3}$ (for PNL 027). Internal standards bromochloromethane and difluorobenzene were not used to quantitate the TICs because coeluting compounds appeared to have greatly altered the signal of the quantitation ions for those two ISs.

The ppmv concentrations are calculated concentration from $\mathrm{mg} / \mathrm{m}^{3}$ and the molecular weight of the analyte. 


$$
\text { TIC in ppmv }=\frac{\operatorname{TIC}\left(\mathrm{mg} / \mathrm{m}^{3}\right) \times 22.4 \mathrm{~L} / \mathrm{mol}}{\text { TIC g mol wt }}
$$

The IS level added to all blank, standard, and sample injections was $18.3 \mathrm{ppbv}$ for bromochloromethane, $20.3 \mathrm{ppbv}$ for 1,4-difluorobenzene, and $18.2 \mathrm{ppbv}$ for chlorobenzene- $\mathrm{d}_{5}$. The IS concentrations were converted from $\mathrm{ppbv}$ to $\mathrm{mg} / \mathrm{m}^{3}$ at STP using a molecular weight of 129.39 ( $\mathrm{g} / \mathrm{mol}$ ) for bromochloromethane, 114.09 for 1,4-difluorobenzene, and 117.6 for chlorobenzene- $\mathrm{d}_{5}$.

\subsection{Analysis Results}

The results from the GC/MS analysis of the tank-headspace samples are presented in Tables 3.1 and 3.2. A representative total ion chromatogram showing the identity of major constituents is given in Figure 3.1.

Table 3.1 lists the quantitative results for compounds listed in Method TO-14. The levels of TO-14 analytes observed in the samples collected from Tank BY-103 were significantly low, close to the quantitation limit $(2 \mathrm{ppb})$.

Table 3.2 lists the semi-quantitative results for the TICs. The predominant species observed in this sample were acetone, 3-methylhexane, butanol, methylcyclohexane, decane, and normal paraffin hydrocarbons (NPHs). The NPHs defined as n-alkanes from $\mathrm{C}_{11}$ to $\mathrm{C}_{15}$ were present in the sample. However, it should be noted that because the SUMMA ${ }^{\mathrm{TM}}$ canister was not heated at the time of analysis, the NPH concentrations listed after the retention time of decane may not be a true accounting of all the NPH in the sample. Similarly, polar compounds, which may adhere to the inside surface of the canister, may also be under represented in this analysis. The total concentration of the TICs was $3.42 \mathrm{mg} / \mathrm{m}^{3}$ for the canister analyzed. A significant amount $\left(0.6 \mathrm{mg} / \mathrm{m}^{3}\right)$ of acetone was observed in the sample. In addition, the amount of NPH and alkanes present in the TIC tables were approximately $25 \%$ of the total analytes identified. 



\subsection{Conclusions}

The concentrations of selected inorganic and organic compounds were determined from in situ samples of the tank headspace of Tank BY-103. The average and standard deviation of the concentration results from inorganic sorbent trains were $30.7 \pm 0.4 \mathrm{ppmv}\left(\mathrm{NH}_{3}\right), \leq 0.1 \mathrm{ppmv}\left(\mathrm{NO}_{2}\right)$, $\leq 0.2 \mathrm{ppmv}(\mathrm{NO}), \leq 0.005 \mathrm{ppmv}(\mathrm{HCN})$, and $8.90 \pm 1.0 \mathrm{mg} / \mathrm{L}$ (vapor mass concentration). The vapor mass concentration is expected to consist largely of water vapors. Minor differences between the individual results of the three $\mathrm{NH}_{3}$ samples matched closely the differences in the quantities of dry air sampled during each sample.

Acetone was found to make up about $18 \%$ of the total concentration of all the organic compounds identified. Contrary to the VSS samples from Tank BY-106, ISS samples from Tank BY103 had a significant amount of NPH and decane present $(25 \%$ of the total concentration of all the identified analytes). The estimated concentration of all the analytes identified in the ISS sample of Tank BY-103 was found to be below the 1-ppmv level.

\subsection{References}

Clauss, T. W., M. W. Ligotke, B. D. McVeety, K. H. Pool, R. B. Lucke, J. S. Fruchter, and S. C. Goheen. 1994. Vapor Space Characterization of Waste Tank 241-BY-104: Results from Samples Collected on 6/24/94. PNL-10208. Pacific Northwest Laboratory, Richland, Washington.

Ligotke, M. W., K. H. Pool, and B. D. Lerner. 1994. Vapor Space Characterization of Waste Tank 241-C-103: Inorganic Results from Sample Job 7B (5/12/94 - 5/25/94). PNL-10172, Pacific Northwest Laboratory, Richland, Washington.

\subsection{Further Reading}

Pacific Northwest Laboratory. Analytical Laboratory Procedure Compendium. Procedures PNLALO-212, -226, -271. PNL-MA-599, Richland, Washington.

Pacific Northwest Laboratory. Quality Assurance Manual, Part 2: Good Practices Standard. PNLMA-70, Part 2, Richland, Washington.

Pacific Northwest Laboratory. Quality Assurance Plan for Activities Conducted by the Analytical Chemistry Laboratory (ACL). MCS-033, Analytical Chemistry Laboratory, Richland, Washington.

Pacific Northwest Laboratory. 1994. Determination of TO-14 Volatile Organic Compounds in Hanford Waste Tank Headspace Samples Using SUMMA TM Passivated Canister Sampling and Gas Chromatographic-Mass Spectrometry Analysis, PNL-TVP-03 (Rev. 0), PNL Technical Procedure, Richland, Washington.

Pacific Northwest Laboratory. 1994. Sample Shipping and Receiving Procedure - DRAFT for PNL Waste Tank Samples. PNL-TVP-07 (Rev. 0), PNL Technical Procedure, Richland, Washington. 
Table 3.1. TO-14 Analysis Results for In Situ Samples Collected from the Headspace of Tank BY-103 in SUMMA ${ }^{\mathrm{TM}}$ Canisters on 5/5/94.

TO-14 Analyte

Dichlorodifluoromethane
Chloromethane
1,2-Dichloro-1,1,2,2-tetraf
Vinyl Chloride
Bromomethane
Chloroethane
Trichlorofluoromethane
1,1-Dichloroethene
Methylene Chloride

1,1,2-Trichloro-1,2,2-trifluoroethane

1,1-Dichloroethane

cis-1,2-Dichloroethene

Chloroform

1,2-Dichloroethane

1,1,1-Trichloroethane

Benzene

Carbon Tetrachloride

1,2-Dichloropropane

Trichloroethene

cis-1,3-Dichloropropene

trans-1,3-Dichloropropene

1,1,2-Trichloroethane

Toluene

1,2-Dibromoethane

Tetrachloroethylene

Chlorobenzene

Ethylbenzene

$\mathrm{p} / \mathrm{m}$-Xylene

Styrene

1,1,2,2-Tetrachloroethane

o-Xylene

1,3,5-Trimethylbenzene

1,2,4-Trimethylbenzene

Chloromethylbenzene, alpha (Benzyl Chloride)

1,3-Dichlorobenzene

1,4-Dichlorobenzene

1,2-Dichlorobenzene

1,2,4-Trichlorobenzene

Hexachloro-1,3-butadiene

\begin{tabular}{cc} 
CAS \# & Mol Wt \\
\hline $75-71-8$ & 120.9 \\
$74-87-3$ & 50.5 \\
$76-14-2$ & 170.9 \\
$75-01-4$ & 62.5 \\
$74-83-9$ & 94.9 \\
$75-00-3$ & 64.5 \\
$75-69-4$ & 137.4 \\
$75-35-4$ & 96.9 \\
$75-09-2$ & 84.9 \\
$76-13-1$ & 187.4 \\
$75-34-3$ & 99.0 \\
$156-59-2$ & 96.9 \\
$67-66-3$ & 119.4 \\
$107-06-2$ & 99.0 \\
$71-55-6$ & 133.4 \\
$71-43-2$ & 78.1 \\
$56-23-5$ & 153.8 \\
$78-87-5$ & 113.0 \\
$79-01-6$ & 131.4 \\
$10061-01-5$ & 111.0 \\
$10061-02-6$ & 111.0 \\
$79-00-5$ & 133.4 \\
$108-88-3$ & 92.1 \\
$106-93-4$ & 187.9 \\
$127-18-4$ & 165.8 \\
$108-90-7$ & 112.6 \\
$100-41-4$ & 106.2 \\
$106-42-3$ & 106.2 \\
$100-42-5$ & 104.2 \\
$79-34-5$ & 167.9 \\
$95-47-6$ & 106.2 \\
$108-67-8$ & 120.2 \\
$95-63-6$ & 120.2 \\
$108-67-8$ & 126.6 \\
$541-73-1$ & 147.0 \\
$106-46-7$ & 147.0 \\
$95-50-1$ & 147.0 \\
$120-82-1$ & 181.5 \\
$87-68-3$ & 260.8 \\
&
\end{tabular}

S4026-A05-079 (a)

PNL $79^{(\text {b) }}$

Concentration

$\begin{array}{cr}\text { ppbv } & \frac{\mathrm{mg} / \mathrm{m}^{3}}{<2} \\ <0.01 \\ <2 & <0.005\end{array}$

$<2<0.02$

$<2<0.01$

$<2<0.01$

$<2<0.01$

$143 \quad 0.88$

$<2<0.01$

$<2<0.01$

$<2<0.02$

$<2<0.01$

$<2<0.01$

$<2<0.01$

$<2<0.01$

$<2<0.01$

$2.3 \quad 0.01$

$<2<0.01$

$<2<0.01$

$<2<0.01$

$<2<0.01$

$<2<0.01$

$<2<0.01$

$57.2 \quad 0.24$

$<2<0.02$

$<2<0.02$

$<2<0.01$

$<2<0.01$

$<2<0.01$

$<2<0.01$

$<2<0.02$

$<2<0.01$

$<2<0.01$

$<2<0.01$

$<2<0.01$

$<2<0.01$

$<2<0.01$

$<2<0.01$

$<2<0.02$

$<2<0.02$

(a) WHC sample identification number.

(b) PNL canister number. 
Table 3.2 Tentatively Identified Compounds and Estimated Concentrations in the Headspace of Tank BY-103 In Situ SUMMATM Canister Sample S4026-

SUM-079 (a) Collected on 5/5/94

Tentatively Identified

Compounds ${ }^{(c)}$

Carbon dioxide

Carbon dioxide

n-Butane

Acetone

n-Pentane

2-Methyl-pentane

2-Butanone

Chlorobromomethane

n-Hexane (coeluent)

1-Butanol

1,4-Difluorobenzene

C7 Alkane ${ }^{(\mathrm{e})}$ (coeluent)

2,3-Dimethylpentane

3-Methylhexane

C7 Alkane $\mathrm{e}^{\mathrm{e})}$

n-Heptane

Methylcyclohexane

Chlorobenzene-d5

3-Heptanone

2-Butoxyethanol

n-Decane

Alkane

C13 Alkene ${ }^{(e)}$

Alkane

n-Tridecane

Alkane

$\mathrm{n}$-Tetradecane
PNL 079(b)

\begin{tabular}{cc}
\multicolumn{3}{c}{ Estimated } & Concentration \\
\hline $\mathrm{mg} / \mathrm{m}^{3}$ & ppmv \\
\hline & \\
(f) & $(\mathrm{f})$ \\
(f) & (f) \\
0.06 & 0.02 \\
0.59 & 0.23 \\
0.05 & 0.02 \\
0.06 & 0.02 \\
0.10 & 0.03 \\
& \\
0.06 & 0.02 \\
0.13 & 0.04 \\
& \\
0.17 & 0.04 \\
0.09 & 0.02 \\
0.24 & 0.05 \\
0.06 & 0.01 \\
0.14 & 0.03 \\
0.31 & 0.07 \\
& \\
0.07 & 0.01 \\
0.14 & 0.03 \\
0.23 & 0.04 \\
0.08 & $(\mathrm{~g})$ \\
0.05 & 0.01 \\
0.14 & $(\mathrm{~g})$ \\
0.45 & 0.05 \\
0.10 & $(\mathrm{~g})$ \\
0.10 & 0.01 \\
&
\end{tabular}

\footnotetext{
(a) WHC sample number

(b) PNL SUMMA ${ }^{\mathrm{TM}}$ canister number

(c) Obtained by mass spectral interpretation and comparison with the EPA/NIST/WILEY Library

(d) Semi-quantitative estimate calculated using concentration of closest eluting internal standard.

(e) Other structural isomers should be considered.

(f) Carbon dioxide is not quantifiable due to the analytical method used.

(g) Molecular weight information is not available for this TIC.
} 


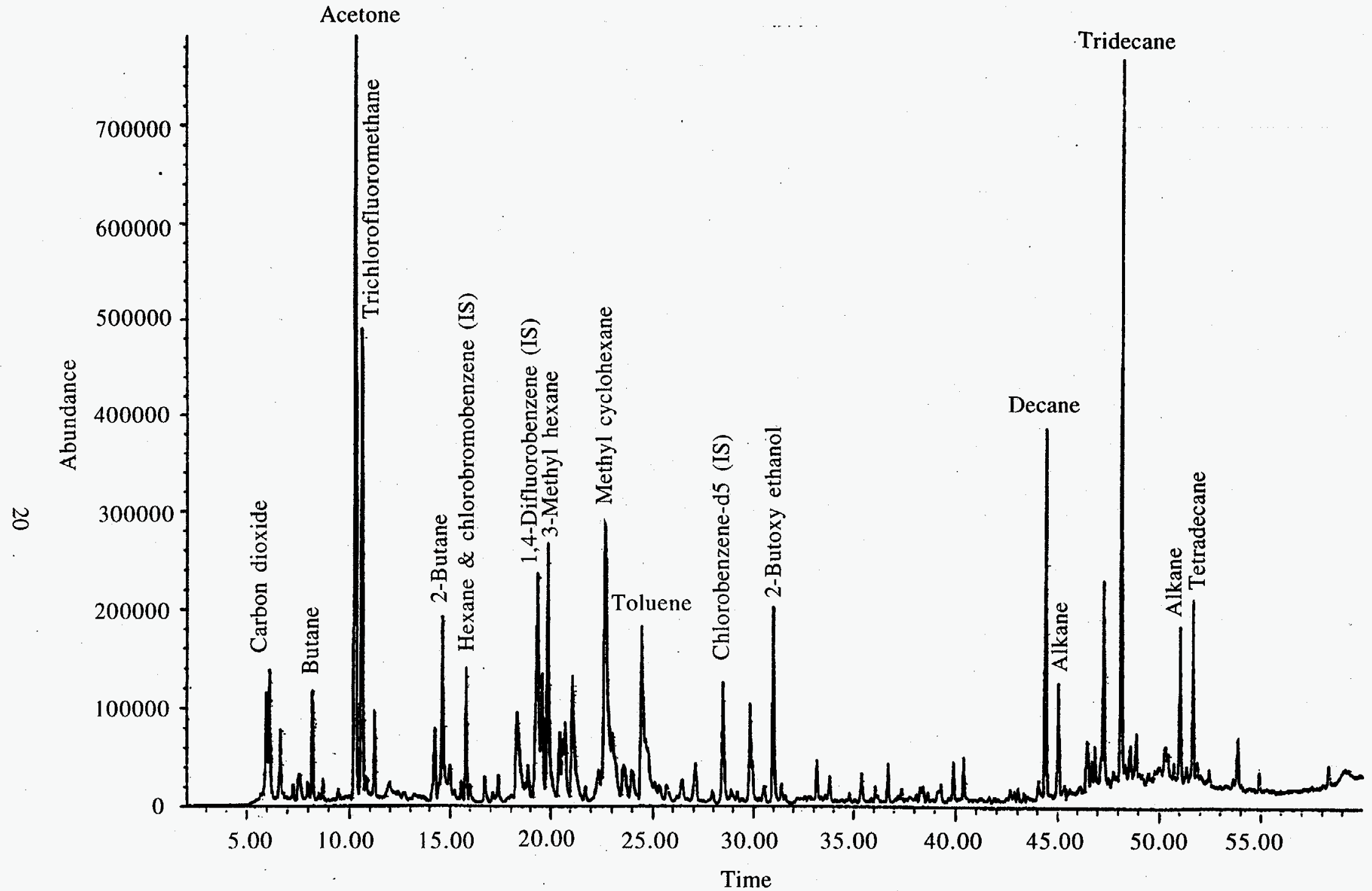

Figure 3.1 GC/MS Chromatogram of Hanford Waste Tank BY-103 In Situ SUMMA ${ }^{\mathrm{TM}}$ Canister Vapor Sample S4026-026-079 Collected on 5/5/94 


\section{Distribution}

No. of

Copies

Offsite

2 DOE Office of Scientific and Technical Information

R. A. Jenkins

Oak Ridge National Laboratory

P.O. Box 2008

Building 4500-5, MS 6120

Oak Ridge, Tennessee 37831-6120
No. of

Copies

Onsite

2. DOE Richland Operations Office

J. M. Clark, S7-54

T, Noble, S7-54

Corps of Engineers

T. W. Gardner-Clayson, A5-19

4 Westinghouse Hanford Company

H. Babad, R2-78

D. R. Bratzel, S7-21 (2)

J. E. Meacham, S7-15

27 Pacific Northwest Laboratory

S. C. Goheen, P8-08 (20)

J. L. Huckaby, K6-55

M. W. Ligotke, P7-59

Technical Report Files (5)

Dist. 1 